\title{
IMPLEMENTASI MODEL KOOPERATIF TIPE STAD \\ TERHADAP HASIL BELAJAR KIMIA SISWA \\ DITINJAU DARI KETERAMPILAN BERPIKIR KREATIF
}

\author{
Hairun Nikmah ${ }^{1}$, Wildan ${ }^{2}$, dan Muntari ${ }^{3}$ \\ ${ }^{1}$ Magister Pendidikan IPA Universitas Mataram \\ 2\&3Fakultas Keguruan dan Ilmu Pendidikan Universitas Mataram \\ hairun_nikmah@rocketmail.com
}

\begin{abstract}
Abstrak
Penelitian ini bertujuan untuk mengetahui interaksi antara model pembelajaran dengan keterampilan berpikir kreatif terhadap hasil belajar kimia siswa. Jenis penelitian yang digunakan adalah eksperimen semu dengan rancangan analisis faktorial $2 \times 2$. Populasi penelitian ini adalah seluruh siswa kelas $\mathrm{X}_{\mathrm{MS}}$ SMAN 1 Narmada yang berjumlah 210 siswa. Sampel penelitian ini diambil dengan teknik simple random sampling sejumlah 83 siswa terdiri dari satu kelas eksperimen 1 dan satu kelas kelas eksperimen 2 dengan perlakuan yang berbeda. Instrumen penelitian berupa lembar angket keterampilan berpikir kreatif dan tes hasil belajar kimia siswa yang dianalisis dengan teknik ANOVA 2 jalur yang sebelumnya diuji normalitas dan uji homogenitas pada taraf signifikansi 0,05. Hasil penelitian menunjukkan tidak ada interaksi antara model pembelajaran dengan keterampilan berpikir kreatif terhadap hasil belajar kimia siswa kelas $\mathrm{X}_{\mathrm{MS}} \mathrm{SMA}$ Negeri 1 Narmada.
\end{abstract}

Kata Kunci: Model Kooperatif Tipe STAD, Hasil Belajar Kimia, Keterampilan Berpikir Kreatif. 


\section{PENDAHULUAN}

Salah satu masalah yang dihadapi dunia pendidikan kita adalah lemahnya proses pembelajaran. Dalam proses pembelajaran, peserta didik kurang didorong untuk mengembangkan kemampuan berpikir. Proses pembelajaran di dalam kelas diarahkan kepada kemampuan peserta didik untuk menghafal informasi tanpa dituntut untuk menghubungkan dengan kehidupan sehari-hari (Sanjaya, 2008).

Solang (2008), mengatakan faktanya sistem sekolah belum maksimal menciptakan suasana belajar yang mengembangkan sistem berpikir kritis, kreatif dan bertanggung jawab. Model pembelajaran ceramah, verbalistik, satu arah monoton masih mendominasi sekolah di Indonesia sehingga tingkatan kemampuan berpikir siswa hanya berada pada tatanan berpikir tingkat rendah yang tidak memiliki penalaran dan kemampuan menyelesaikan masalah nyata. Hasil penelitiannya menunjukkan bahwa, siswa yang diintervensi atau dilatih dengan berpikir praktikal-sintetik-analitik memiliki performance yang lebih tinggi dari yang tidak dilatih berpikir praktikal-sintetik dan analitik (berpikir analitis, sintesis pada masalah dunia nyata).

Berpikir kreatif sebagai bagian dari higher order of thinking merupakan kemampuan yang penting dikuasai untuk pembelajaran sepanjang hayat (life long learning). Peningkatan berpikir kreatif dapat diupayakan dengan menerapkan model kooperatif tipe STAD secara baik dan benar. Menurut Sabandar (2008), berpikir kreatif sesungguhnya adalah suatu kemampuan berpikir yang berawal dari adanya kepekaan terhadap situasi yang sedang dihadapi, bahwa situasi itu terlihat atau teridentifikasi adanya masalah yang sedang dihadapi, bahwa situasi itu terlihat atau teridentiikasi adanya masalah yang ingin diselesaikan dan munculnya unsur originalitas gagasan dalam benak seseorang.

Berdasarkan hasil proxy pretes di SMAN 1 Narmada, nilai rata-rata 37.33 jauh di bawah kriteria ketuntasan minimal (KKM) yang ditetapkan yaitu 75. Usaha yang diperlukan untuk meningkatkan hasil belajar kimia dan keterampilan berpikir kreatif siswa diperlukan inovasi dan kreatifitas guru untuk

20 BIOTA: Jurnal Tadris IPA Biologi FITK IAIN Mataram 
memilih dan menerapkan model pembelajaran yang sesuai dengan pembelajaran kimia.

Berkaitan dengan hal tersebut, guru harus mampu menciptakan pembelajaran yang dapat membuat siswa ikut berperan aktif. Salah satu model pembelajaran yang dapat melibatkan siswa secara aktif dalam pembelajaran adalah model kooperatif tipe STAD. Pembelajaran kooperatif tipe STAD ini merupakan model pembelajaran kooperatif dengan menggunakan kelompok-kelompok kecil dengan jumlah anggota tiap kelompok 4-5 orang siswa secara heterogen yang diawali dengan penyampaian tujuan pembelajaran, penyampaian materi, kegiatan kelompok, kuis, dan penghargaan kelompok (Wena, 2009). Sedangkan menurut Slavin (2005), adanya penghargaan kelompok di dalam model pembelajaran STAD membuat siswa lebih termotivasi untuk meningkatkan hasil belajarnya. Belajar kooperatif mengkondisikan siswa belajar dari pengalaman dan berpartisipasi aktif dalam menyelesaikan persoalan atau permasalahan yang diberikan oleh guru. Adanya interaksi siswa dalam kelompok memungkinkan siswa tidak segan bertanya pada teman sekelompoknya untuk dapat memahami materi pelajaran yang diberikan oleh guru.

Penelitian yang dilaksanakan oleh Ishaq Nuriadin, dkk (2013) menunjukkan bahwa terdapat hubungan yang signifikan antara kemampuan berpikir kreatif dengan hasil belajar dan kemampuan berpikir kreatif memberikan kontribusi sebesar $31,2 \%$ terhadap hasil belajar siswa. Penelitian sejenis juga dilakukan oleh Anisa, dkk (2013), model pembelajaran kooperatif tipe STAD dapat membuat proses pembelajaran kimia di kelas menjadi lebih menarik sehingga mendorong siswa untuk mencintai pelajaran kimia yang akhirnya dapat meningkatkan hasil belajar kimia siswa. Hal ini disebabkan model pembelajaran kooperatif tipe STAD dapat membangkitkan rasa keingintahuan siswa, merangsang siswa bereaksi baik secara fisik maupun emosional, serta dapat membantu guru untuk menciptakan suasana belajar menjadi lebih hidup, tidak monoton dan tidak membosankan sehingga dapat meningkatkan hasil belajar kimia siswa. 


\section{METODE PENELITIAN}

Penelitian ini menggunakan rancangan penelitian eksperimental semu (Quasy Experimental Design). Pengambilan sampel dilakukan dengan teknik simple random sampling sehingga terpilih dua kelas yang menjadi sampel yaitu kelas $\mathrm{X}_{\mathrm{MS} 3}$ sebagai kelas eksperimen 1 dan $\mathrm{X}_{\mathrm{MS} 2}$ sebagai kelas eksperimen 2 .

Instrumen yang digunakan dalam mengumpulkan data adalah tes hasil belajar kimia berupa soal uraian yang digunakan untuk mengukur hasil belajar kimia siswa dan angket untuk mengukur ketermpilan berpikir kreatif. Analisis data hasil penelitian ini dilakukan dengan analisis statistik menggunakan analisis varians (ANOVA) 2 jalur.

Sebelum analisis data dilakukan terlebih dahulu dilakukan uji prasyarat analisis statistik, yaitu: (1) uji normalitas menggunakan Kolmogorov-Smirnov untuk mengetahui apakah sebaran data sampel berdistribusi normal atau tidak, (2) uji homogenitas menggunakan uji Levene's untuk mengetahui apakah varians antara kelompok data satu dengan yang lainnya homogen/tidak secara segnifikan 5\%. Bila semua persyaratan uji hipotesis terpenuhi selanjutnya dilakukan analisis ANOVA 2 Jalur ini untuk mengetahui interaksi antara model pembelajaran dengan keterampilan berpikir kreatif terhadap hasil belajar kimia siswa kelas $\mathrm{X}_{\mathrm{MS}}$ SMA Negeri 1 Narmada.

\section{HASIL PENELITIAN}

\section{Deskripsi Hasil Belajar Kimia dan Keterampilan Berpikir Kreatif}

Nilai keterampilan berpikir kreatif diperoleh dari lembar angket yang diberikan sebelum mulai pembelajaran dan hasil belajar diperoleh dari nilai post-test yang diberikan. Perolehan nilai keterampilan berpikir kreatif dan hasil belajar kimia siswa pada kelas eksperimen 1 dan kelas eksperimen 2 dalam bentuk grafik terlihat pada Gambar 1, bahwa hasil belajar kimia dengan KBK tinggi belum tentu lebih tinggi daripada hasil belajar kimia dengan KBK rendah pada materi struktur atom

\footnotetext{
22 BIOTA: Jurnal Tadris IPA Biologi FITK IAIN Mataram
} 
dan sistem periodik unsur. Hal ini bertolak belakang dengan penelitian sebelumnya (Amalia, dkk, 2013) bahwa prestasi belajar siswa dengan kreativitas tinggi nilainya lebih tinggi daripada prestasi belajar siswa dengan kreativitas rendah. Penelitian Ishak, dkk. (2012), terdapat hubungan yang positif anatara KBK dengan hasil belajar siswa.

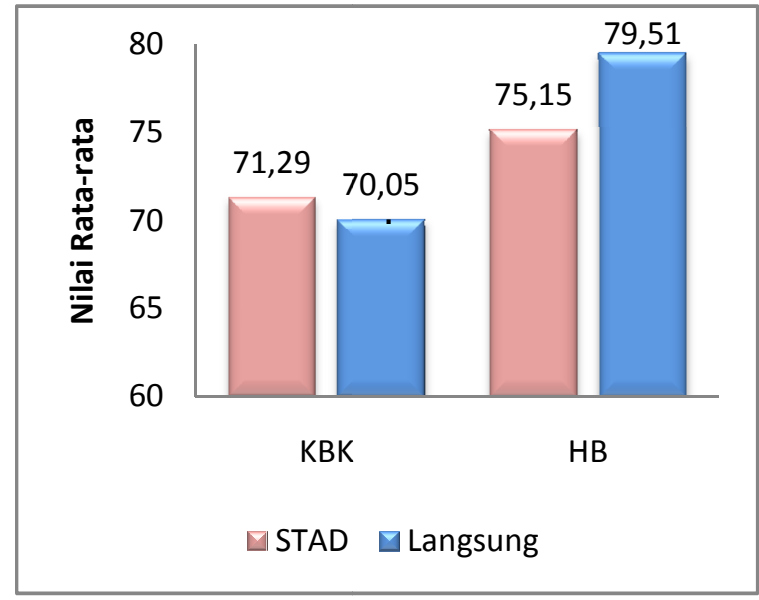

\section{Gambar 1}

Grafik Nilai Rata-rata KBK dan HBK Siswa

\section{Pengujian Statistik}

Berdasarkan hasil uji prasyarat disimpulkan bahwa data tersebut terdistribusi normal dan homogen. Oleh karena itu, uji hipotesis dengan ANOVA 2 jalur dapat dilanjutkan. Hasil uji hipotesis menunjukkan pada taraf signifikan $5 \%$ diperoleh nilai $F_{\text {hitung }}$ sebesar 0,0044. Harga $F_{\text {hitung }}$ tersebut lebih kecil dari $F_{\text {tabel }}$ $\left(F_{\text {hitung }}<\mathrm{F}_{\text {tabel }}=0,0044<3.96\right)$ artinya Ha ditolak dan Ho diterima 


\section{PEMBAHASAN}

Berdasarkan hasil analisis data tersebut, menunjukkan tidak adanya interaksi antara model pembelajaran dengan keterampilan berpikir kreatif terhadap hasil belajar kimia siswa. Mengacu pada hasil uji hipotesis menggunakan ANOVA dua jalur, pada taraf signifikan $5 \%$ diperoleh nilai $\mathrm{F}_{\text {hitung }}$ sebesar $0.0044<$ $\mathrm{F}_{\text {tabel }}=3.96\left(\mathrm{~F}_{\text {hitung }}<\mathrm{F}_{\text {tabel }}=0.0044<3.96\right)$ artinya Ho diterima sehingga dapat disimpulkan "Tidak ada interaksi antara keterampilan berpikir kreatif dengan model pembelajaran terhadap hasil belajar kimia siswa kelas XMS SMAN 1 Narmada".

Tidak adanya interaksi model pembelajaran dan keterampilan berpikir kreatif terhadap hasil belajar kimia siswa dikarenakan model pembelajaran kooperatif tipe STAD yang diterapkan selama penelitian masih baru dan dan belum dikenal oleh siswa sebelumnya. Selama ini proses pembelajaran yang dilakukan guru dalam mengajarkan kimia cenderung mengandalkan metode ceramah dan pemberian tugas yang cenderung berpusat pada guru dan kurang melibatkan siswa secara aktif dan kurang membiasakan siswa untuk mampu berpikir kreatif dalam belajar sehingga penerapan model pembelajaran kooperatif tipe STAD yang dilakukan secara spontan atau hanya dilakukan selama 5 kali pertemuan melalui penelitian ini masih belum dapat membiasakan siswa untuk mengembangkan keterampilan berpikir kreatifnya.

Menurut Utami Munandar (2009), bahwa tingkah laku kreatif dapat terwujud dari kognitif (kemampuan berpikir) kreatif dan afektif (sikap dan nilai). Semakin kreatif seseorang semakin dimiliki ciri-ciri individu kreatif yang meliputi keterampilan berpikir lancar, keterampilan berpikir luas, keterampilan orisinil, keterampilan merinci dan menilai. Hal ini didukung oleh pernyataan Idrus (2000), pada dasarnya unsur kreatif ada pada setiap orang, namun yang membedakannya adalah kemampuan untuk mengembangkannya antara individu satu dengan individu lainnya yang relatif berbeda. Mereka yang berada dalam lingkungan pendidikan tertentu ada kalanya dituntut untuk selalu berkreasi, sementara pada model lainnya tuntutan ini tidak penuh. Selain itu, persoalan jenis kelamin terkadang menjadi penentu

24 BIOTA: Jurnal Tadris IPA Biologi FITK IAIN Mataram 
seseorang. Meski demikian, secara garis besar dapat dicermati minimal tiga perbedaan menonjol antara mereka yang kreatif dan yang kurang kreatif, yaitu dalam cara berpikir, berkepribadian dan kebiasaan. Ketiga hal tersebut bagi individu kreatif akan dilakukannya secara berbeda dengan yang dilakukan individu lainnya, serta bebas dari pengaruh orang lain.

Model pembelajaran kooperatif adalah model pembelajaran yang bercirikan melibatkan secara optimal siswa atau peserta didik dalam kegiatan pembelajaran terutama melalui kegiatan diskusi kelompok. Dalam kenyataannya di kelas dalam pelaksanaan pembelajaran tersebut dalam kegiatan kelompok masih didominasi oleh siswa-siswa yang mempunyai kemampuan kognitif tinggi umumnya. Hal itu dapat dilihat dari perbedaan ratarata nilai hasil belajar kimia siswa, yaitu sebesar 75.15 untuk kelas eksperimen 1 dan 79.51 untuk kelas eksperimen 2 serta ketuntasan klasikal kelas eksperimen dan eksperimen 2 yaitu $62.16 \%$ dan $82.61 \%$.

Dari data tersebut dapat disimpulkan bahwa keterampilan berpikir kreatif siswa memberikan pengaruh yang sama pada kelompok siswa yang diajar menggunakan model pembelajaran kooperatif tipe STAD maupun model pembelajaran konvensional. Penyebab tidak terjadinya interaksi antara model pembelajaran dengan keterampilan berpikir kreatif terhadap hasil belajar kimia siswa adalah karena model pembelajaran tersebut temasuk model pembelajaran yang baru yang mereka terima di kelas $\mathrm{X}_{\mathrm{MS}}$ SMAN 1 Narmada Tahun Pelajaran 2014/2015. Siswa yang mempunyai keterampilan berpikir rendah sudah terbiasa dengan pembelajaran konvensional membutuhkan waktu yang cukup lama untuk meningkatkan keterampilan berpikir kreatif dan hasil belajarnya.

\section{KESIMPULAN DAN SARAN}

Berdasarkan hasil penelitian dapat disimpulkan bahwa tidak ada interaksi antara model pembelajaran dengan keterampilan berpikir kreatif terhadap hasil belajar kimia siswa 
kelas $\mathrm{X}_{\mathrm{MS}}$ SMAN 1 Narmada. Keterampilan berpikir kreatif perlu pelatihan pada peserta didik sedini mungkin agar peserta didik terbiasa untuk berpikir pada tatanan tingkat tinggi.

\section{DAFTAR PUSTAKA}

Amalia, S. P. A. Ashadi \& Nugroho A CS. 2013. Studi Komparasi Model Pembelajaran STAD Dengan Menggunakan Media Animasi Macromedia Flash Player dan Molymod Pada Pembelajaran Kimia Materi Pokok Ikatan Kovalen Ditinjau Dari Kreativitas Siswa Kelas X SMAN 2 Sukoharjo Tahun Pelajaran 2011/2013. Jurnal Pendidikan Kimia (JPK), Vol.2 No. 2 Tahun 2013. Program Studi Pendidikan Kimia Universitas Sebelas Maret.

Idrus, Muhammad. 2000. Kreativitas Siswa SLTPN 2 dan SLTPN 4 Kotamadya Yogyakarta. Universitas Islam Indonesia. Yogyakarta.

Munandar, U. 2009. Pengembangan Kreativitas Anak Berbakat. Jakarta: Rineka Cipta.

Nuriadin, I \& Perbowo, S.K. 2013. Analisis Korelasi Kemampuan Berpikir Kreatif Matematika Terhadap Hasil Belajar Matematika Peserta Didik SMP Negeri 3 Lurangung Kunungan Jawa Barat. Jurnal Ilmiah Program Studi Matematika STKIP Siliwangi Bandung, vol 2, No. 1, Februari 2013.

Sabandar, J. 2008. Berpikir Reflektif. Makalah Prodi Pendidikan Matematika SPS. UPI.

Sanjaya, W. 2008. Strategi Pembelajaran Berorientasi Standar Proses Pendidikan. Jakarta: Kencana Prenada Media Group.

Slavin, Robert E. 2005. Cooperative Learning Teori, Riset dan Praktik. Bandung: Nusa media.

Wahyuningtyas, F. A. Ibnu, S.M. Nugroho, R. 2013. Penerapn Model Kooperatif Tipe STAD Untuk Meningkatkan Hasil Belajar Pada Materi Hidrolisis Garam Untuk Siswa Kelas XI IPA Semester 2 SMA Negeri 9 Malang Tahun Ajaran 2012/2013. Jurusan Kimia FPMIPA Universitas Negeri Malang.

Wena, M. 2008. Strategi Pembelajaran Inovatof Kontemporer. Malang: Bumi Aksara.

26 BIOTA: Jurnal Tadris IPA Biologi FITK IAIN Mataram 